\title{
The changing interplay between European cities and intermodal transport networks (1970s-2010s)
}

\author{
Justin BERLI, César DUCRUET, Romain MARTIN, Sevil SETEN \\ Centre National de la Recherche Scientifique (CNRS) \\ UMR 8504 Géographie-cités \\ 13 rue du Four, F-75006 Paris, France
}

This is the pre-final version of the book chapter published in Carpenter A. and Lorenzo R.

(Eds.) (2020) European Port Cities in Transition, Springer, pp. 241-263.

\begin{abstract}
European cities, like most of the world's cities, are to some degree dependent upon maritime transport for their development, as more than $90 \%$ of seaborne trade volume is carried by sea. This also applies to Europe's external trade. While cities possessing ports play a crucial role in the distribution of goods traffic in such a context, the maritime influence exerted by global trade on non-port, inland cities have not been so far studied from a combined sea-land perspective. The results show a differentiation of the European territory in terms of modal specialization, core-periphery, polycentricity, and intermodal centrality / accessibility. We map the maritime specialization of European cities in recent decades, showing that combined sea-land centrality has stable but different relationships according to the type of place considered. The conclusion discusses the outcomes of our results for policy and further research on coupled networks and urban studies.
\end{abstract}

Keywords: Europe; Geographical Information System (GIS); Maritime transport; Network analysis; Port cities

\section{Introduction}

The relationships between ports and cities have been analysed from numerous perspectives in the academic literature and beyond. Although "maritime and land transportation modes play a vital role in the growth of urban places" (Lugo, 2015, p. 322), the differences between port cities from non-port cities remains scantily debated. Despite a consensus that port cities are specific due to their coastal location, direct connection to commodity trade through maritime transport, and the presence of related economic activities, they underwent spatial and functional separation. Many scholars (e.g. Slack, 1989; O'Connor 1987; McCalla et al., 2001; Jacobs et al., 2010, 2011) have discussed that cities, rather than ports, attract tertiary maritime firms. In developed countries, cities and regions hosting ports often perform below national average in terms of wage levels and economic impacts (Fujita and Mori, 1996; Lemarchand, 2000; De Langen, 2007; Grobar, 2008; Hall, 2009; Gouvernal and Slack, 2015). Such evidence has been 
confirmed through a number of models and case studies about the physical and functional separation between ports and cities in the last decades (Bird, 1963; Hoyle, 1989; Murphey, 1989; Norcliffe et al., 1996). Other studies have demonstrated the temporal and geographic variability of such a phenomenon (Brocard, 1988; Ducruet and Lee, 2006; Lee et al., 2008; Ducruet and Itoh, 2016), echoing earlier critiques of the central place theory ignoring the port function, using the concept of gateway (Burghardt, 1970; Bird, 1973). In Europe, port cities were found to be demographically larger (Vleugels, 1969) and economically richer (Lever, 1995) than other cities. In the case of Mexico, Lugo (2015, p. 328) highlighted that "port locations are significant nodes in the spatial network because they affect transport logistics to cities". Other authors have argued in favor of more invisible relationships stronger than the urbanistic changes taking place on the waterfront, such as: political science (De La Gorce, 2003); economic and political geography (Hall, 2003; Clark and Hall, 2010); transport geography (Charlier, 1992); and urban geography (Slack, 1989; Lee and Ducruet, 2009; Van der Berghe et al., 2018). While such relationships may be measured, they were also often approached qualitatively and theoretically (Hall, 2010; Hesse, 2010; Hall and Jacobs, 2012; Monios et al., 2018) or through case studies (El Hosni, 2017; Hesse, 2018). This has also been confirmed by a vast number of collective works about the past, present, and future of European port cities (Hayot, 1988; Hoyle and Pinder, 1992; Lawton and Lee, 2002; Warsewa, 2006).

This chapter contributes to a better understanding of port-city relationships based on the macrolevel and intermingling of continental and global networks. Traditionally, European cities have been studied based on: networks of roads (Dupuis and Stransky, 1996; Guttiérez and Urbano, 1996; Bruinsma and Rietveld, 1998; Vickerman et al., 1999); railways and airlines (Cattan 1995; Dobruszkes et al., 2011), multinational firms (Rozenblat and Pumain, 1993); and scientific collaborations (Comin, 2009). While urban networks in Europe (and elsewhere) constitute an ancient topic (Pumain, 1996), one of the first analyses of European and world cities from a maritime network perspective is very recent (Ducruet et al., 2018). Such study was ambitious by its temporal scope (1890-2010) and geographic scale (world). This study of cities linked by water using inter-city shipping data demonstrated a declining port-city relationship overtime for cities hosting ports, but a growing one for cities distant from nearby ports at the level of the extended city-region. One of the main explanations given by the authors was that the increased importance of land transport (trucking) was the key to understand the actually unchanged port-city correlation except from expanded spatial distance between place of cargo handling and place of production and/or consumption. It was, thus, demonstrated that in Europe, port concentration and road network configuration motivated important shifts of export flows (see Hoare, 1986). This confirms the need to combine landward and maritime aspects in the study of port cities.

Only a few studies have considered both road and maritime networks despite the paramount importance of intermodalism today (e.g. Van Klink and Van den Berg, 1998), but also in the past (Marnot, 2005; Bretagnolle, 2015). Spatial models combining foreland and hinterland such as the port triptych (Vigarié, 1979) as well those depicting port system evolution have depicted the inland shift of port activities in Europe and elsewhere (Van Klink, 1998; Notteboom and Rodrigue, 2005; Rodrigue and Notteboom, 2010; Monios and Wilmsmeier, 2012). Other works documented the rise of dry / inland ports (Raimbault et al., 2016) and the expanding territorial embedding of shipping lines through vertical integration (Franc and Van der Horst, 2010). Rarely has been the city the unit of analysis, as in the more quantitative studies of Chapelon (2006) on the regional accessibility of European ports, and Guerrero et al. (2017) on European 
NUTS-3 regions' maritime and landside connectivity. Other studies (e.g. Nelson, 2008; Tavasszy et al., 2011) combined sea-land networks at the world scale but without combining their results with specific urban indicators. Other research has been made at the national level such as in the case of Spain, but also with regions rather than cities as the unit of analysis (see Zanon Moura et al., 2018). Only recently, port cities have been analysed based on their situation in maritime and road networks, in Australia (Berli et al., 2018) and the British Isles (Ducruet and Berli, 2018). The latter studies demonstrated that the intermodal or sea-land centrality of cities was better related to urban population than single (i.e. land or maritime) centrality, suggesting that a single network was not sufficient to understand urban development patterns and dynamics. Their choice of island countries was motivated by the absence of border effects to run first tests with assumption that in such territories, port and urban hierarchies are quite overlapped.

The European-wide perspective has the potential to provide new evidence about the relative importance of each network in the combined centrality of port and non-port cities, and the possible relationship between composite centrality and the urban and port hierarchy. The temporal approach allows to observe spatial evolutions in Europe's maritime centre of gravity and to identify trends or trajectories in the maritime specialization of cities. Europe as a whole offers a fertile ground to further test the linkage between maritime flows and (non-port) urban development as it is mainly a continental market served by coastal ports (Figure 1). Such a specific configuration explains fierce port competition to catch "contestable hinterlands", such as Austria (De Langen, 2004) and Northeastern France (Guerrero, 2014), while local and continental economic linkages vary across ports and across regions (Merk et al., 2013; Marques-Ramos, 2016). Beyond European and transport/urban issues, combining a global maritime network and a continental land network raises questions of a different nature. Some questions that arise from the previous arguments include: How do planar (road) and non-planar (maritime) networks interact? Which are the key and common nodes and how do they benefit from this coupling? Is the merged network more robust? How should or could the European port system be organized according to simple rules of accessibility and centrality and can such results provide room for further debate? For cities, does this intermodal analysis stand in line with wider trends such as the relationship between size and diversity as observed in urban geography and regional economics? In other words, our main hypothesis is that cities' centrality is more significantly related to urban hierarchies in a combined rather than in a single network.

\section{[Insert Figure 1 about here]}

The remainder of this chapter is as follows. Section 2 introduces the methodsnecessary to construct and model a European sea-land transport network to which are assigned harmonized population data for cities over the period 1978-2008. This period was chosen given the recent character of the road network but possibilities for deeper historical perspectives are discussed in conclusion. Section 3 is the core of the chapter, delivering our main results in terms of the relationship between cities and sea-land centrality. The last and concluding section draws the lessons taken from such an exercise and proposes avenues for further research and policy.

\section{Modelling a European sea-land network of cities}


This chapter uses for an extended view of Europe, from Iceland to Turkey and from the Canary Islands to Russian plains, even considering North Africa as suggested by earlier studies on world regionalization (Didelon et al., 2008). Such a choice has the advantage of avoiding the arbitrary cut of the road network and the urban system based on political borders. Taking into account the whole Mediterranean and Black seas was also encouraged by critical works in area studies about seas and oceans as vectors rather than obstacles or barriers (Lewis and Wigen, 1999).

Shipping data used in this chapter is rather unusual as it condenses the inter-port movements of most of the world fleet. Vessel calls between adjacent ports led us to create a global O-D matrix within which "Europe" and its ports is only one part of the whole. Links (or edges) are weighted due to the inclusion of vessel tonnage during four continuous months of navigation for each of the retained years: 1978, 1983, 1988, 1993, 1998, 2003, and 2008 (i.e. March, June, September, and December). This was made possible due to the existence of one untapped data source, namely Lloyd's List Intelligence, thereby allowing the application of several complex network measures. The global maritime network was built as a graph where ports are nodes and voyages between them are linked, summing the full capacity of vessels to both of them at each call. Such maritime flows were, in addition, assigned to a maritime grid in order to represent its spatial distribution within Europe and its evolution overtime. In this section it is briefly explained how had the grid been constructed, with regard to the combination of maritime links and road links.

\subsection{The maritime grid}

Modelling vessels' paths throughout the globe has been an important part of our work as it allows us to visualize real maritime flows. The detailed workflow of the grid's creation has already been discussed in previous publications (Bunel et al., 2017; Ducruet and Berli, 2018). It should be noted that the grid is the result of an iterative process that divided the earth into rectangular meshes - keeping a higher density around shorelines - while their centroids (i.e. centre of gravity) were linked to one another (Figure 2). This automatic generation of a maritime graph represents every potential route a vessel may use to sail from its departure port to its destination port. A new feature has been incorporated for this analysis and will be explained in a more detailed fashion; indeed, we decided to manually enhance the grid to ensure that its sections follow the natural shape of the shorelines and avoid overlapping continents. Those modifications allow visualizations at greater scales (e.g. coastal shipping flows), while preserving the lightness of the grid; such an exercise removed unnecessary links in dense areas and increased their amount in scarce areas. As such, connections between ports and the grid got closer to reality.

\section{[Insert Figure 2 about here]}

\subsection{The road graph}

Modelling a road network implies determining the nodes of the final graph. Each port was categorized by its direct belonging to an urban area and/or its (potential) use as a maritime gateway for a distant city (see Ducruet et al., 2018 for a deeper explanation of this method). In the latter case, certain cities do not have direct sea access (e.g. Athens vs. Piraeus/Perama) or 
developed modern port facilities away from their historical centre (e.g. Marseilles vs. Fos-surMer). Nevertheless, those cities were added to the graph, along with continental ones, based on the Natural Earth ${ }^{1}$ dataset. Thus, ports and cities are considered being nodes of the graph, thereby necessitating their connection with one another.

To achieve that goal, it was decided to use the powerful spatial indexes provided by a PostgreSQL/PostGIS database as it bears the most potential in terms of time-efficiency concerning large tables of spatial entities. A rather straightforward Python script allowed us to automatically create those links until manual corrections were applied. We used OpenStreetMap ${ }^{2}$ road sections due to their detailed information about the global road network including the categorisation of segments. To alleviate intensive queries that often reached computational limitations, we used a quadtree to divide the Earth into evenly-dense tiles in terms of cities and ports, thus ensuring an equally dense road network in each tile. As such, every following step describing a process on a given tile will induce the use of the surrounding tiles as the road network is often continuous across continents (Figure 3).

\section{[Insert Figure 3 about here]}

From raw data to a routable graph, five different steps were followed. The first two mainly aimed sparsification (i.e. density reduction); we decided to discriminate the main road network, or structural backbone connecting cities, by keeping only higher rank road sections (motorway, trunk, and primary). This network was converted into polygons that represent each area enclosed by the main road system. Then, each area overlapping the ocean space was considered coastal and was thereby used to extract low-ranked road sections along the shore. The second step was the extraction of low-ranked road sections surrounding ports; this depended on the rank of the ports' closest road as well as on its distance from the main road network. It allowed us to keep only the roads which connect each port to the main network and, consequently, to cities. The third step is the creation of a routable network based on the density-reduced OpenStreetMap dataset. Costs were calculated according to speed limits and sections length; when the speed limit was missing, it was added in consideration to its rank. Then, the fourth step used Dijkstra's shortest path algorithm to extract road sections that are necessarily used to connect each port and city to one another. A weighted minimal road network was to be used for visualization but mainly to create an actual graph to allow calculating accessibility indices (see Rodrigue and Ducruet, 2018 for a review).

The last step is crucial as it transforms the concrete network into an abstract graph consisting of nodes representing cities or ports, linked together by weighted arcs. Rough buffers were first created around cities and ports, intersected them with continents to avoid sea overlapping, and calculated once again shortest paths between each node and kept those which only intersected two buffers. Using this method aimed to keeping direct links between cities and ports while avoiding links passing through (or close to) a third one. As the road network substantially depends of specific features of the territory (topography, coastline, deserts, rivers, etc.), every created arc was thoroughly checked: some of them removed where the shortest path was considered too close to a city - taking into consideration its size - to lighten the graph while

\footnotetext{
${ }^{1}$ https://www.naturalearthdata.com/

2 https://www.openstreetmap.org/
} 
keeping its coherence. Lastly, we included the Channel Tunnel as a road link only for the years post-1994.

In the end, such a hybrid network comprising no less than 4,900 nodes allowed us calculating fundamental network indices using TULIP software ${ }^{3}$ (Auber, 2004) as follows:

Clustering coefficient: , i.e. the actual proportion of connected neighbors in the total possible number of connected neighbors;

Betweenness centrality: , i.e. the number of occurrences on shortest paths throughout the network;

Degree centrality: , i.e. the number of adjacently connected neighbors.

\section{Constructing a European urban population database}

\subsection{Harmonizing urban population overtime}

Our urban population database is the outcome of the merger and harmonization of four different world urban population databases, namely Citypopulation ${ }^{4}$ (1990-2015), Populstat ${ }^{5}$ (18802005), World Gazetteer ${ }^{6}$ (2010), and Geopolis ${ }^{7}$ (1950-1990). We chose the definition of the city as an economic and morphological entity, beyond administrative boundaries, thus including adjacent localities. European cities were selected in two ways: (a) as important nodes in the modeled road network (see previous section), and (b) nodes hosting (and being closely located to) ports. Population was collected whenever possible from the aforementioned sources for 2,794 cities every five years. We selected the closest year to matching traffic data as follows: 1980 for 1978, 1985 for 1983, 1990 for 1988, 1995 for 1993, 2000 for 1998, 2005 for 2003, and 2010 for 2008.

The main goal of population data selection and harmonization had been to provide time series as complete as possible, leave a minimum of unfilled cells. Such a process has faced, however, several issues. First, each source defines the "city" as an administrative (i.e. communes, district) or economic, morphological (agglomerations, urban area) unit, so that population data varied dramatically between years and between sources. In this chapter and with reference to the work of Ducruet et al. (2018) on cities connected by water, we kept the later definition whenever possible. Otherwise and mainly for smaller cities, those having long-term information on its inhabitants were kept according to their administrative definition, because the agglomeration or urban area is often restrained to - or overlaps - such an entity. Second, certain cities witnessed sudden fall or rise of population even within the same source. In some cases, this is explained by important events such as wars, migrations, epidemics, etc. In others, true reasons may relate to changes in census definition and data collection methods or to other unknown reasons. Third, numerous places with less than 500 inhabitants often were not recorded in the aforementioned sources, such as tiny villages or small islands notably around the Baltic Sea. Third, we had difficulty with assigning the right nationality to certain border cities, since the

\footnotetext{
${ }^{3}$ http://tulip.labri.fr/TulipDrupal/

4 https://www.citypopulation.de/

5 http://www.populstat.info/

${ }^{6}$ discontinued website

${ }^{7}$ Moriconi-Ebrard (1994)
} 
urban area extends across two countries; this was checked by a quick search to assign the actual country. Lastly, several names suffered from distortions due to the presence of specific characters within place names, such as «MÃ@rida » (Merida) in Spain or «JyvÃaskylÃa » in Finland. We thus made another check when comparing sources to find the proper spelling based on international English standards.

\subsection{Estimating missing population data}

Interpolation methods were used to estimate missing urban population data along the whole 1880-2015 period, although this chapter focuses on the recent period 1978-2008. Such methods could not be applied to cities having only one or a few values. Two methods were used: Cubic Spline and Akima. The first method is a polynomial interpolation by segments. A different polynom is used between each existing value to interpolate the missing ones. Cubic splines are thus continuous functions formed by a maximum of three degrees. However, the disadvantage of such a method is that cubic splines tend to oscillate around extreme or aberrant values (e.g. peak values), as in the case of population data is affected by sudden shocks such as humanitarian crises or large migration flows (Figure 4).

\section{[Insert Figure 4 about here]}

The Akima method is an optimization of the $b$-splines method which does not suffer from such oscillations. This is due to the fact that interpolation functions used for the data interval $\left[X_{i}, X_{i+1}\right]$ solely depends on functions at intervals between data $\mathrm{i}-2, \mathrm{i}-1, \mathrm{i}, \mathrm{i}+1$ and $\mathrm{i}+2$ therefore five points ${ }^{8}$. Our choice had been to run two variations of each of those two methods. First, we applied the two methods on a dataset where missing data between adjacent years were averaged, based on the hypothesis that in the absence of a major change or shock, population evolved regularly overtime. Interpolation methods allow estimating unknown population data between two known dates. Yet, over one-year interval the method does not work and provides aberrant results, thus motivating us to adopt extrapolation methods. In the case of population growth, the simplest method consisted in applying a growth rate to t- 1 value year in order to unravel the $\mathrm{t}$ value year. If $\mathrm{Pt}$ is the population data at year $\mathrm{t}$, the growth rate formula (in percentage) at year $\mathrm{t}$ is as follows:

$C_{t}=100 \cdot \frac{P_{t}-P_{t-1}}{P_{t-1}}$

Population at year +1 is calculated by multiplying year $t$ population by this growth rate $\left[C_{t}\right]$ as follows:

$P_{t+1}=P_{t} C_{t}$

We calculated population growth rates during the 20 years preceding the missing population data. Because our population database was built on a 5-year basis, we calculated growth rates over the previous five, ten, fifteen, and twenty years. The growth rate five years prior to the unknown population data is considered as the reference rate, while other rates $5 \%$ over this value were excluded. We then calculated the average of the remaining rates to obtain an overall growth rate. Because such a choice is arbitrary as it supposes that population evolved the same

\footnotetext{
${ }^{8}$ These methods were applied using the opensource library Alglib: http://www.alglib.net/
} 
than the latest known rate, averaging growth rates allows a reasonable overview of variations that may have occurred between several quinquennia.

We ran a model validation test to make a choice between our two interpolation methods. We selected sixteen cities and their population over the longer time period 1880-2015 and intentionally suppressed known data at strategic dates to retrieve it before running the methodology on the whole sample of European cities. The four methods (i.e. Cubic Spline, Akima, and their respective variants) were thus applied to selected cities and our results were compared with real (known) data. By calculating the sum of Euclidean distances between each original population data and its corresponding estimated population data, it appeared that the Akima method, by filling missing data through averaging, was the most significant.

We then calculated the average population size of cities along the chosen study period (19802010) by types of cities, showing that river (port) cities dominate by far other city types. This can be explained that in Europe in particular, upstream and inland river cities are favored due to their historical role in dominating with landward and maritime networks (see Vance, 1970; Brunet, 1986; Brocard et al., 1995). River ports and cities are historically favored by their multimodal nature: canals, rivers, upstream estuaries, and road networks.

\section{A complex network analysis of European cities}

\subsection{Port-city specialization and hierarchy}

Based on the constructed methodology on networks and cities, our objective was to test the mutual influence of population and sea-land centrality throughout Europe (Figure 5). Overall, we observe a slight decline of correlation overtime. This suggests that the urban hierarchy had become a less important determinant. In addition, most correlations exhibit a relatively low significance, the maximum value being 0.332. Despite such rather disappointing results, a clear logic underlies Table 1. For betweenness centrality and degree centrality, a common trend is a higher significance for maritime cities, i.e. coastal cities hosting a port. Yet, degree centrality being a more local measure, river (port) cities exhibit superior correlation with population, especially for the period 1993-2003; while all cities taken together exceed the score of continental cities (without port) except for the years 1988 and 1998-2008.

Such results are in line with geographers's works such as Brocard (1988) for whom port cities are "exceptions to the organization rules of urban networks": continental port cities (river, upstream) "cumulate land-based centrality and regional distribution while performing less on the deep-sea side (e.g. Rouen, Antwerp), while coastal port cities "cannot dominate the urban system but have the advantage of the maritime function (e.g. Le Havre, Halifax)". The inverse clustering coefficient, a local measure of "hub power", is the lowest for maritime port cities, the highest for river (port) cities, and continental (non-port) cities surpass the score of all cities for the years 1988, 1993-2008.

Traffic volume measured in deadweight tons (DWTs) is another facet of port city activity. Compared with centrality scores, the correlation is slightly more significant with total traffic, especially for maritime cities for which the coefficient always surpasses 0.3 and sometimes 0.4 . Yet, it is between total traffic and centrality scores where the highest significance is obtained, with the exception of the clustering coefficient that remains below average. Betweenness 
centrality in relation to DWTs is nearly close to 1 (perfect correlation) for river cities, around 0.7 for maritime cities, while for degree centrality the same pattern can be observed although with slightly lower coefficients. Such results suggest that the urban dimension of nodes is much less determinant than their overall traffic when it comes to explain their combined centrality.

\section{[Insert Figure 5 about here]}

Another way to testing the interplay between sea-land centrality and urban hierarchy is the calculation of average centrality per city size classes (Figure 6). Cities were ranked according to the method of percentiles (or quantiles) using Wessa (2018) software, resulting in classes containing an equal number of cities, from the smallest (class 1) to the largest (class 5) cities. Class 6 is conserved to comparing cities' scores to non-urban places (ports) on average along the study period.

In many ways, our results confirm the work of Ducruet et al. (2018) on the world's cities connected by shipping networks, although in the present case centrality scores include continental, road networks. The common feature is that the bigger the cities, the higher the average centrality all scores included. In addition, what is striking is that non-urban places (class 6) nearly always exhibit a lower score than all other categories. This demonstrates the role of urban places in enhancing trade and shipping activities, as cities provide ports with labor, skills, value-added activities, and specific experience as well as a community of actors that cannot be found in isolated ports (see Hall and Jacobs, 2012). The progression from smallest to largest cities is nearly mathematical. This leads us to formulate a kind of stylized fact whereby cities are at the center of multiple flows and networks as already observed in the wider academic literature on cities and flows (Derudder and Witlox, 2010; O'Connor, 2010; Hall and Hesse, 2012). In terms of intermodal or multiplex structure of the network, such results also confirm the fact that more diversified ports in general develop larger centrality and traffic size than other, more specialized ports, especially when aggregated into urban areas (Ducruet, 2013).

A closer look at our results was performed by dividing each city type ratio by all cities ratio. Such an exercise could highlight the fact that continental (non-port) cities always performed better than all cities taken together on average, especially for the inverse clustering coefficient. This can explain the strong effect of planar structure (road) over sea-land (hybrid) structure since these cities have a dominant position continentally. In comparison, inland (port) cities located on rivers exhibit the same behavior but mainly at the top of the hierarchy, and even in a stronger way than continental (non-port) cities, for the inverse clustering coefficient. The two other indicators, contrary to continental cities, reach values over " 1 " for the class of the largest cities, meaning that such intermodal crossroads are stronger due to their hosting of one or more ports and their demographic size. Maritime (port) cities are even stronger especially for betweenness and degree centrality as they surpass the score of all cities by 7 to 10 times, suggesting that maritime networks are their advantage over other cities. The same occurs for the inverse clustering coefficient, but without such a gap as their score is equivalent to the one of inland (river, port) cities. In terms of degree centrality, maritime non-urban ports perform 2 times more on average than inland (port) cities.

\section{[Insert Figure 6 about here]}

\subsection{Mapping the combined centrality of European cities}


Before analyzing the distribution of centrality across European ports and cities, it is necessary to have an overview on how have different or all nodes reacted to the merger between road and maritime networks (Table 1). The results correspond to the ratio between sea-land centrality and road centrality, with gains or losses. In all cases, for cities and ports, losses have been, on average, higher than gains although one may witness a slight increase of gains overtime and a rather stable value for losses depending on the category. This would suggest that as a continental market, Europe in general does not benefit from being connected to maritime trade networks as it has already a strong internal, landward connectivity. Cities such as Dusseldorf, Madrid, Paris, and Moscow, as mentioned earlier, are better connected by airline networks and because they use multiple maritime gateways for the rest of their trade, the maritime connectivity does not seem to provide them with a stronger position. Continental (non-port) cities have the lowest gain among all categories given their "central place" situation.

\section{[Insert Table 1 about here]}

There is a wide diversity of cases behind those aggregated and averaged numbers, as seen in the following figures 7-10. At first sight, we observe a strong opposition between coastal (gains) and inland nodes (losses) as mentioned earlier. Yet, many nodes with high absolute centrality are coastal port cities, while the highest gains can be observed for island ports and cities. This result is realistic but, at the same time, is an artificial effect by which small or medium-sized islands such as Corsica, Sicily, Balearic Islands, Crete, Cyprus, the British Isles, Gotland, Aland, and parts of Estonia have such a minor road network that connecting maritime flows inevitably witness highest centrality gains. It also applies to enclaves such as Ceuta. Several large port cities, whatever their location, exhibit high absolute centrality, being very central in both sea and land networks, such as the Le Havre-Hamburg range, London, Gothenburg, St. Petersburg, Porto, Lisbon, Barcelona, Marseilles, Genoa, Venice, and Piraeus, all of them gaining from becoming connected to maritime flows. What is more interesting is the "outlier effect" by which certain large (port) cities lose centrality contrary to what could have been expected, such as Oslo, Bordeaux, Seville, Valencia, Riga, and Istanbul. Oslo, Bordeaux and Seville have in common to be upstream estuarine (or fjord) cities being less accessible to largest vessels, while Riga and Istanbul may still not have sufficiently developed as maritime nodes so that their road centrality remains their main strength. The case of Valencia remains rather unique in this respect. Interestingly however, numerous nodes around the Black Sea and Baltic Sea exhibit low but positive gains, suggesting that such relatively closed seas remain a key advantage to their European and global accessibility.

\section{[Insert Figures 7-10 about here]}

The pattern in 1988 is nearly overlapped with the previous one, notwithstanding a deeper inland concentration of maritime gains around southern Germany / Switzerland and in Eastern Europe. Le Havre is still the port of the Northern Range with the highest centrality gain, probably revealing its inland or hinterland deficient connectivity. However, Paris changed from gain to loss between 1978 and 1988. In 1998, the same happened to London compared with previous years, as well as to many other Great Britain cities, partly due to the opening of the Channel Tunnel in 1994. Malta joins, since the development of Mediterranean transshipment hubs in the 1990s, the category of high gains for island ports and cities. The inland penetration of maritime centrality has remained rather constant, and nodes with high sea-land centrality remain more or less the same. Some nodes are figured only for the needs of cartography, such as Tarifa (Spain) 
and Brunsbuttel (Germany) as they are considered passage points rather than ports in the Lloyd's database. Lastly in 2008, we clearly observe that Ireland is much more advantaged than Great Britain in terms of relative gains, as it has remained an island. What has increased overtime is the density of higher absolute centralities around the "blue banana" area, i.e. the European megalopolis between London and Milano where most of Europe's economic wealth, population, and infrastructure concentrate. Yet, largest centrality inland cities within this megalopolis remain negatively affected by the connection with maritime flows, as they are already prominent in the road network. The European core-periphery pattern, even excluding the island effect, keeps being an essential feature of the whole territory as seen in Figure 1.

\section{Conclusions}

This chapter investigated for the first time the ambivalence between maritime centrality and landward centrality for both port and non-port cities in the case of Europe. This exercise started with the hypothesis that the historical concentration of economic wealth should have an influence on our results, based on a well-known core-periphery spatial structure. Thanks to the collection and harmonisation of both urban, maritime, and road data, we calculated the global centrality (or accessibility) of selected European places in this bi-layered network. These necessitated heavy development efforts on the geomatics side to building a worldwide maritime grid and to modelling a European road network. Another main motivation of our study was to evaluate the maritime and sea-land centrality of port and non-port cities overtime, from the late 1970 s to the late 2000 s.

Such analysis has implications in many domains. In network science for instance, it is one rare empirical analysis of a hybrid network, both planar and non-planar, especially its evolution and its geographic features. Most of the time, the planar and non-planar dimensions keep being separated although it is at center stage when it comes to concrete applications such as intermodalism and specialization. Therefore, this chapter combines those two dimensions and study the resulting entity as a single object, echoing early studies of the foreland-hinterland continuum in geography (see $\mathrm{Ng}$ and Ducruet, 2014 for an extensive review). It also contributes to urban studies by the fact that the European demographic hierarchy remains, overtime, a strong determinant of intermodal centrality. This was not so obvious to find out since many ports have been developed outside cities and at the contrary, many cities have seen their port function declining if not vanishing in the last decades (Hoyle, 1989). The average correlation between centrality and urban population was stronger for maritime cities, in particular for betweenness and degree centralities, due to their connectivity to overseas markets.

Further research is envisaged in multiple ways. First, a deeper historical depth is possible given the time scope of Lloyd's shipping data (since 1880), but what remains lacking is a printed or already vectorised road network for Europe. Second, our tools and data will make it possible to run the same and/or complementary analyses at the world scale, but again, maps of global road networks before the 1980s are hard to obtain. It would also be useful to also refine the road network by weighting its links depending on the changing pavement rate of countries, and perhaps, run multi-level analyses using other national-level indicators such as GDP or population to better explain the results. Third, we restricted this chapter to the ratio between combined centrality and road centrality using only one main indicator, betweenness. We may complement such an approach by the ratio between combined centrality and maritime centrality 
as well, and use additional indicators such as the Shimbel index (or closeness centrality). Arcs may be weighted in terms of travel time or distance to get closer to spatial network analyses (Barthelemy, 2015), to avoid an analysis based on mainly topological features (i.e. binary graph: presence or absence of links). Running the same analyses excluding islands may refine the results and make more evident the inland penetration of maritime circulations, which are blurred by islands' exceptional values. Qualitative discussions on certain nodes and regions will be more and more necessary to verify the fitness of our results compared with the reality of European and global logistics patterns, the presence of specific socio-economic activities such as port clusters and other.

\section{Acknowledgements}

The research leading to these results has received funding from the European Research Council under the European Union's Seventh Framework Programme (FP/2007-2013) / ERC Grant Agreement n. [313847] "World Seastems".

\section{References}

Auber D. (2004). Tulip: A huge graph visualisation framework. In: Mutzel P., Junger M. (Eds.), Graph Drawing Software, Berlin \& Heidelberg: Springer, Mathematics and Visualization, pp. 105-126. https://doi.org/10.1007/978-3-642-18638-7_5

Barthelemy M. (2015). Spatial networks: Tools and perspectives. In: Ducruet C. (Ed.), Maritime Networks: Spatial Structures and Time Dynamics, Routledge: London \& New York, pp. 50-60.

Berli J., Bunel, M. and Ducruet C. (2018). Sea-land interdependence in the global maritime network: the case of Australian port cities. Networks and Spatial Economics, Online First, https://doi.org/10.1007/s11067-018-9403-4

Bird J. (1963). The major seaports of the United Kingdom. London: Hutchinson.

Bird J. (1973). Of central places, cities and seaports. Geography, 58, 105-118.

Bretagnolle A. (2015). City systems and maritime transport in the long term. In: Ducruet C. (Ed.), Maritime Networks: Spatial Structures and Time Dynamics, Routledge: London \& New York, pp. 27-36.

Brocard M. (1988). Les relations fonctionnelles entre le port et la ville [The functional relationships between the port and the city]. Paper presented at the $1^{\text {st }}$ International Conference Cities and Ports, Le Havre, France.

Brocard M., Lecoquierre B. and Mallet P. (1995). Le chorotype de l'estuaire européen [The chorotype of the European estuary]. Mappemonde, 3: 6-7.

Bruinsma F. and Rietveld P. (1998). The accessibility of European cities: Theoretical framework and comparison of approaches. Environment and Planning A, 30(3), 499-521. https://doi.org/10.1068/a300499 
Brunet R. (1986). La carte modèle et les chorèmes [Model-maps and chorems]. Mappemonde, 4: http://www.mgm.fr/PUB/Mappemonde/M486/p2-6.pdf 3

Bunel M., Bahoken F., Ducruet C., Lagesse C., Marnot B., Mermet E. and Petit S. (2017). Geovisualizing the sail-to-steam transition through vessel movement data. In: Ducruet C. (Ed.), Advances in Shipping Data Analysis and Modeling. Tracking and Mapping Maritime Flows in the Age of Big Data, Routledge Studies in Transport Analysis, Routledge: London \& New York, pp. 189-205.

Burghardt A.F. (1970). A hypothesis about gateway cities. Annals of the Association of American Geographers, 61(2), 269-285.

Chapelon L. (2006). L'accessibilité, marqueur des inégalités de rayonnement des villes portuaires en Europe [Accessibility as a marker of disparities of influence among port cities in Europe]. Cybergeo: European Journal of Geography, 345: https://cybergeo.revues.org/2463. https//doi.org/10.4000/cybergeo.27810

Charlier J. (1992) The regeneration of old port areas for new port uses. In: Hoyle B.S., Pinder D.A. (Eds.), European Port Cities in Transition, London: Belhaven Press, pp. 137-154.

Clark A. and Hall P.V. (2010). Maritime ports and the politics of reconnection. In: Desfor G., Laidley J., Schubert D., Stevens Q. (Eds.), Transforming Urban Waterfronts: Fixity and Flow, Abingdon: Routledge, pp. 17-34.

Comin M.N. (2009). Réseaux de villes et réseaux d'innovation en Europe: Structuration du système des villes par les réseaux de recherche sur les technologies convergentes [Urban and innovation networks in Europe: Structuring city-systems through research networks on convergent technologies] . Unpublished $\mathrm{PhD}$ dissertation in geography, University of Paris-I Panthéon-Sorbonne.

De Langen P.W. (2004). Port competition and selection in contestable hinterlands; the case of Austria. European Journal of Transport and Infrastructure Research, 7(1), 1-14. https://doi.org/10.18757/ejtir.2007.7.1.3370

De Langen P.W. (2007). The economic performance of seaport regions. In: Wang J.J., Olivier D., Notteboom T.E., Slack B. (Eds.), Ports, Cities, and Global Supply Chains, Aldershot: Ashgate, pp. 187-202.

Derudder B. and Witlox F. (2010). Commodity Chains and World Cities. Wiley-Blackwell.

Didelon C., Grasland C. and Richard Y. (2008). Atlas de l'Europe dans le Monde [Atlas of Europe in the world]. Paris: Reclus/La Documentation française.

Dobruszkes F., Lennert M. and Van Hamme G. (2011). An analysis of the determinants of air traffic volume for European metropolitan areas. Journal of Transport Geography, 19(4), 755762. https://doi.org/10.1016/j.jtrangeo.2010.09.003

Ducruet C. (2013). Network diversity and maritime flows. Journal of Transport Geography, 30, 77-88. https://doi.org/10.1016/j.jtrangeo.2013.03.004

Ducruet C. (2017). Multilayer dynamics of complex spatial networks: the case of global maritime flows (1977-2008). Journal of Transport Geography, 60, 47-58. https://doi.org/10.1016/j.jtrangeo.2017.02.007 
Ducruet C. and Berli J. (2018). Measuring land-sea interactions at ports and cities: insights from geomatics and network analysis. Portus Online, 35: https://portusonline.org/measuring-landsea-interactions-at-ports-and-cities-insights-from-geomatics-and-network-analysis/

Ducruet C. and Itoh H. (2016). Regions and material flows: Investigating the regional branching and industry relatedness of port traffic in a global perspective. Journal of Economic Geography, 16(4), 805-830. https://doi.org/10.1093/jeg/lbv010

Dupuis G. and Stransky V. (1996). Cities and highway networks in Europe. Journal of Transport Geography, 4(2), 107-121. https://doi.org/10.1016/0966-6923(96)00004-X

Fujita M. and Mori T. (1996). The role of ports in the making of major cities: Selfagglomeration and hub-effect. Journal of Development Economics, 49, 93-120. https://doi.org/10.1016/0304-3878(95)00054-2

Grobar L.M. (2008). The economic status of areas surrounding major U.S. container ports: Evidence and policy issues. Growth and Change, 39(3), 497-516. https://doi.org/10.1111/j.14682257.2008.00435.x

Gutiérrez J., Urbano P. (1996). Accessibility in the European Union: The impact of the transEuropean road network. Journal of Transport Geography, 4(1), 15-25. https://doi.org/10.1016/0966-6923(95)00042-9

Hall P.V. (2009). Container ports, local benefits and transportation worker earnings. Geojournal, 74(1), 67-83. https://doi.org/10.1007/s10708-008-9215-z

Hall P.V. and, Hesse M. (2012). Cities, Regions and Flows. London \& New York: Routledge.

Hall P.V. and Jacobs W. (2012). Why are maritime ports (still) urban, and why should policy makers care? Maritime Policy and Management, 39(2), 189-206. https://doi.org/10.1080/03088839.2011.650721

Hayot A. (1988). The relationship between the port and its town. In: Prospects for Urban Development in Port Towns in Europe, International Colloquy, Piraeus, $29^{\text {th }}$ September-02 ${ }^{\text {nd }}$ October 1986, Final Report, Council of Europe, Urban Renaissance in Europe Study Series, Strasbourg, $\mathrm{n}^{\circ} 34$.

Hesse, M. (2010). Cities, material flows and the geography of spatial interaction: urban places in the system of chains. Global Networks, 10(1), 75-91. https://doi.org/10.1111/j.14710374.2010.00275.x

Hoare A.G. (1986). British ports and their export hinterlands: A rapidly changing geography. Geografiska Annaler B, 68(1), 29-40. https://doi.org/ 10.2307/490915

Hoyle B.S. (1989). The port-city interface: Trends, problems and examples. Geoforum, 20(4), 429-435. https://doi.org/10.1016/0016-7185(89)90026-2

Hoyle B.S. and Pinder D.A. (1992). European Port Cities in Transition. London: Belhaven Press.

Jacobs W., Ducruet C. and De Langen P.W. (2010). Integrating world cities into production networks: The case of port cities. Global Networks, 10(1), 92-113. https://doi.org/10.1111/j.1471-0374.2010.00276.x 
Jacobs W., Koster H.R.A. and Hall P.V. (2011). The location and global network structure of maritime advanced producer services. Urban Studies, 48(13), 2749-2769. https://doi.org/10.1177/0042098010391294

Lawton R. and Lee R. (2002). Population and Society in Western European Port Cities, c. 1650-1939. Liverpool: Liverpool University Press.

Lee S.W. and Ducruet C. (2006). Waterfront redevelopment and territorial integration in Le Havre (France) and Southampton (UK): Implications for Busan, Korea. Ocean Policy Research, 21(2): 127-156.

Lee S.W. and Ducruet C. (2009). Spatial glocalization in Asia-Pacific hub port cities: A comparison of Hong Kong and Singapore. Urban Geography, 30(2), 161-184. https://doi.org/10.2747/0272-3638.30.2.162

Lee S.W., Song D.W. and Ducruet C. (2008). A tale of Asia's world ports: The spatial evolution in global hub port cities. Geoforum, 39(1): 372-385. https://doi.org/10.1016/j.geoforum.2007.07.010

Lemarchand A. (2000). La Dynamique des Ports: Mesures de la Valeur et des Emplois, Emplois et Valeur des Mesures [Port dynamics: Measures of value and employment, use of values and measures]. Paris: DATAR.

Lever W.F. (1994). Regional economic growth and port activities in European cities. Paper presented at the $5^{\text {th }}$ International Conference Cities and Ports, Dakar, Senegal, pp. 309-316.

Lewis M.W. and Wigen K. (1999). A maritime response to the crisis in area studies. The Geographical Review, 89(2), 161-168. https://doi.org/ 10.2307/216084

Lugo I. (2015). Interplay between maritime and land modes in a system of cities. In: Ducruet C. (Ed.), Maritime Networks: Spatial Structures and Time Dynamics, Routledge: London \& New York, pp. 322-329.

Marnot B. (2005). Interconnexion et reclassements: L'insertion des ports français dans la chaîne multimodale au XIXe siècle [Interconnection and ranking change: The insertion of French ports in the $19^{\text {th }}$ century multimodal chain]. Flux, 59(1), 10-21. https://doi.org/10.3917/flux.059.0010

Marquez-Ramos, L. (2016). Port facilities, regional spillovers and exports: Empirical evidence from Spain. Papers in Regional Science. 95(2), 329-351. https://doi.org/10.1111/pirs.12127

McCalla R.J., Slack B. and Comtois C. (2001). Intermodal freight terminals: locality and industrial linkages. Canadian Geographer, 45, 404-413. https://doi.org/10.1111/j.15410064.2001.tb01190.x

Merk O., Manshanden W.J.J. and Dröes M.I. (2013). Inter-regional spillovers of seaports: The case of Northwest Europe. International Journal of Transport Economics, 40(3), 401-417.

Monios J., Bergqvist R. and Wovenius J. (2018). Port-centric cities: The role of freight distribution in defining the port-city relationship. Journal of Transport Geography, 66, 53-64. https://doi.org/10.1016/j.jtrangeo.2017.11.012

Monios J. and Wilmsmeier G. (2012). Giving a direction to port regionalisation. Transportation Research Part A, 46(10), 1551-1561. https://doi.org/10.1016/j.tra.2012.07.008 
Moriconi-Ebrard F. (1994). Geopolis: pour Comparer les Villes du Monde [Geopolis: comparing the world's cities]. Paris: Economica.

Nelson A. (2008). Travel time to major cities: A global map of accessibility. Global Environment Monitoring Unit, Joint Research Centre of the European Commission, Ispra, Italy.

Ng A.K.Y. and Ducruet C. (2014). The changing tides of port geography (1950-2012). Progress in Human Geography, 38(6), 785-823. https://doi.org/10.1177/0309132513516178

Norcliffe G., Bassett K. and Hoare T. (1996). The emergence of postmodernism on the urban waterfront. Journal of Transport Geography, 4(2), 123-134. https://doi.org/10.1016/09666923(96)00005-1

Notteboom T.E. and Rodrigue J.P. (2005). Port regionalization: Towards a new phase in port development. Maritime Policy and Management, 32(3), 297-313. https://doi.org/10.1080/03088830500139885

O'Connor K. (1987). The location of services involved with international trade. Environment and Planning A, 19(5), 687-700. https://doi.org/10.1068/a190687

O'Connor K. (2010). Global city-regions and the location of logistics activity. Journal of Transport Geography, 18(3), 354-362. https://doi.org/10.1016/j.jtrangeo.2009.06.015

Pumain D. (1996). Urban Networks in Europe. John Libbey Eurotext.

Raimbault N., Jacobs W. and van Dongen F. (2016). Port regionalisation from a relational perspective: The rise of Venlo as Dutch international logistics hub. Tijdschrift voor Sociale en Economische Geografie, 107(1), 16-32. https://doi.org/10.1111/tesg.12134

Rodrigue J.P. and Ducruet C. (2018). Graph theory: definition and properties. The Geography of Transport Systems, Paper 10, https://transportgeography.org/?page_id=5976 [accessed October 2018].

Rodrigue J.P. and Notteboom T.E. (2010). Comparative North American and European gateway logistics: the regionalism of freight distribution. Journal of Transport Geography, 18(4), 497-507. https://doi.org/10.1016/j.jtrangeo.2010.03.006

Rozenblat C. and Pumain D. (1993). The location of multinational firms in the European urban system. Urban Studies, 30(10), 1691-1709. https://doi.org/10.1080/00420989320081671

Slack B. (1989). The port service industry in an environment of change. Geoforum, 20(4), 447457. https://doi.org/10.1016/0016-7185(89)90028-6

Tavasszy L.A., Minderhoud M., Perrin J.F. and Notteboom T.E. (2011). A strategic network choice model for global container flows: Specification estimation and application. Journal of Transport Geography, 19(6), 1163-1172. https://doi.org/10.1016/j.jtrangeo.2011.05.005

Van den Berghe K., Jacobs W. and Boelens L. (2018). The relational geometry of the port-city interface: Case studies of Amsterdam, the Netherlands, and Ghent, Belgium. Journal of Transport Geography, 70, 55-63. https://doi.org/10.1016/j.jtrangeo.2018.05.013

Van Klink, H.A. (1998). The port network as a new stage in port development: The case of Rotterdam. Environment and Planning A, 30(1), 143-160. https://doi.org/10.1068/a300143 
Van Klink G.A. and Van den Berg G.C. (1998). Gateways and intermodalism. Journal of Transport Geography, 6(1), 1-9. https://doi.org/10.1016/S0966-6923(97)00035-5

Vance J.E. (1970). The Merchant's World. The Geography of Wholesaling. Englewood Cliffs: Prentice-Hall.

Vickerman R., Spiekermann K. and Wegener M. (1999). Accessibility and economic development in Europe. Regional Studies, 33(1): 1-15. https://doi.org/10.1080/00343409950118878

Vigarié A. (1979). Ports de Commerce et Vie Littorale [Trading ports and coastal life]. Paris: Hachette.

Vleugels R.L.M. (1969). The economic impact of ports on the regions they serve and the role of industrial development. Paper presented at the International Association of Ports and Harbors (IAPH), Australian Conference, pp. 239-247.

Warsewa G. (2006). The Transformation of European Port Cities. Final Report on the New EPOC Port City Audit, Bremen University.

Wessa P. (2018). Free Statistics Software, Office for Research Development and Education, version 1.2.1, https://www.wessa.net/ [Accessed December 2018]

Zanon Moura T.G., Garcia-Alonso L. and del Rosal I. (2018). Influence of the geographical pattern of foreign trade on the inland distribution of maritime traffic. Journal of Transport Geography, 72, 191-200. https://doi.org/10.1016/j.jtrangeo.2018.09.008 


\begin{tabular}{|c|c|c|c|c|c|}
\hline City type & Change & 1978 & 1988 & 1998 & 2008 \\
\hline \multirow{3}{*}{ Continental } & Loss & 0.1714 & 0.1463 & 0.1325 & 0.1406 \\
\cline { 2 - 6 } & Gain & 0.0002 & 0.0002 & 0.0008 & 0.0005 \\
\cline { 2 - 6 } & All & 0.1328 & 0.1151 & 0.1075 & 0.1147 \\
\hline \multirow{3}{*}{ River } & Loss & 0.2404 & 0.1987 & 0.2067 & 0.2055 \\
\cline { 2 - 6 } & Gain & 0.0003 & 0.0006 & 0.0011 & 0.0014 \\
\cline { 2 - 6 } & All & 0.1380 & 0.1089 & 0.1239 & 0.1184 \\
\hline \multirow{3}{*}{ All } & Loss & 0.2792 & 0.2879 & 0.2894 & 0.3022 \\
\cline { 2 - 6 } & Gain & 0.0047 & 0.0060 & 0.0097 & 0.0089 \\
\cline { 2 - 6 } & All & 0.0909 & 0.0924 & 0.1082 & 0.1121 \\
\cline { 2 - 6 } & Loss & 0.2140 & 0.2023 & 0.1997 & 0.2082 \\
\cline { 2 - 6 } & Gain & 0.0027 & 0.0047 & 0.0066 & 0.0070 \\
\hline \multirow{3}{*}{ Port } & All & 0.1080 & 0.1017 & 0.1098 & 0.1137 \\
\cline { 2 - 6 } & Loss & 0.2074 & 0.1929 & 0.1996 & 0.2142 \\
\cline { 2 - 6 } & Gain & 0.0014 & 0.0024 & 0.0049 & 0.0031 \\
\hline
\end{tabular}

Table 1: Average centrality differentials by city type and port, 1978-2008 


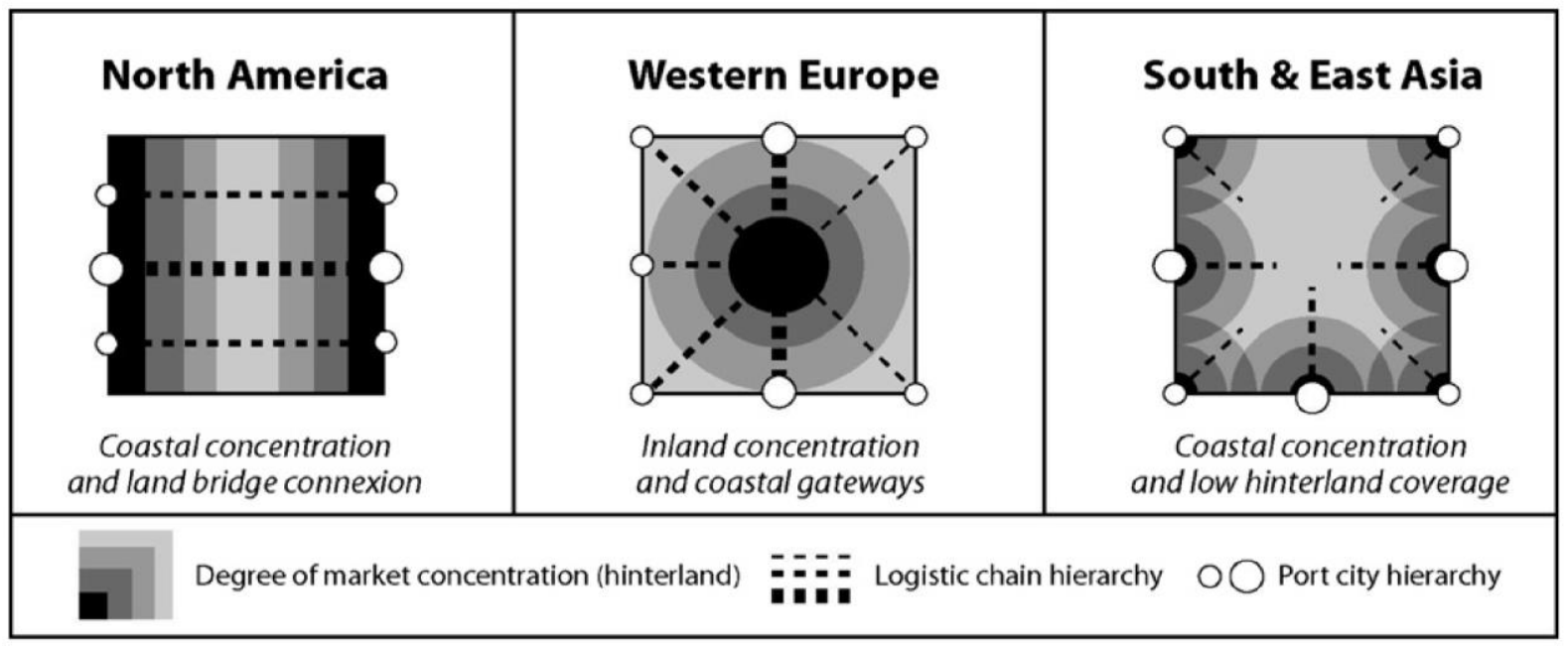

Figure 1: Spatial patterns of main economic regions

Source: Lee et al., 2008

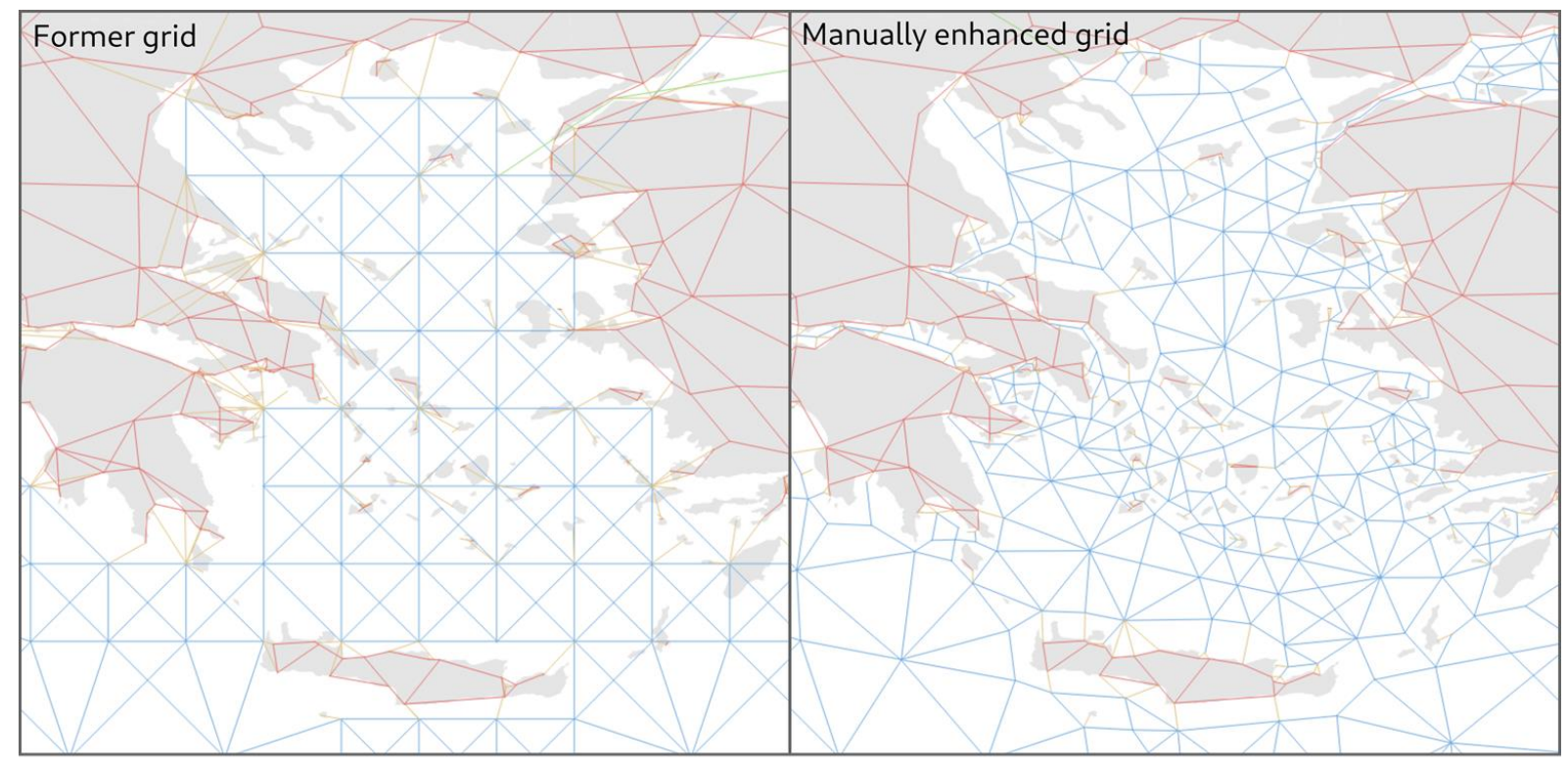

Maritime grid

Road graph

Fluvial grid

Ports connections

Figure 2: Manual enhancements of the maritime grid along the shoreline

Source: own elaboration 


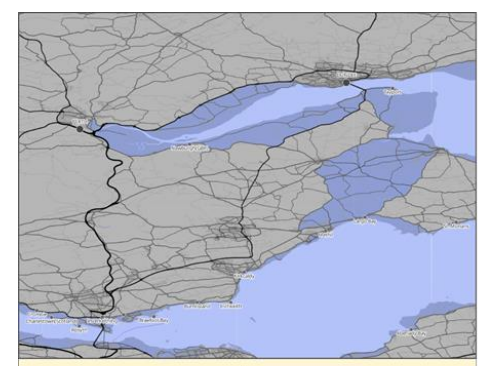

I.

Road network's structural 'backbone' extraction and littoral areas creation

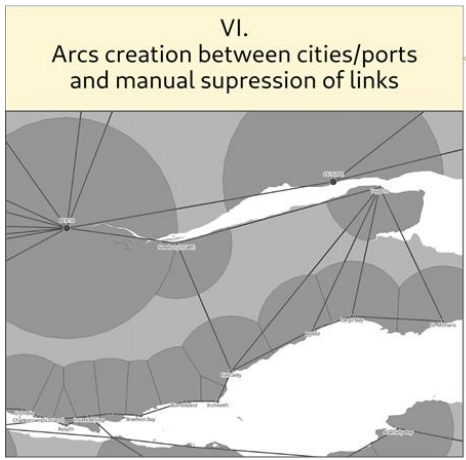

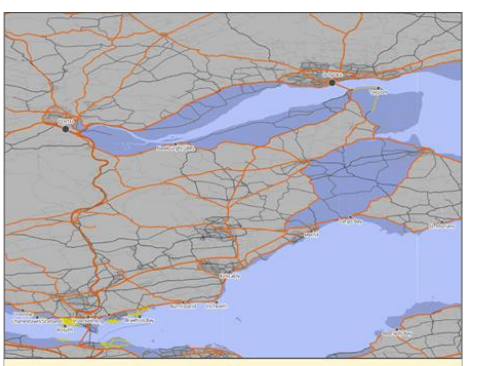

II.

Lower rank road sections extraction around ports in littoral areas

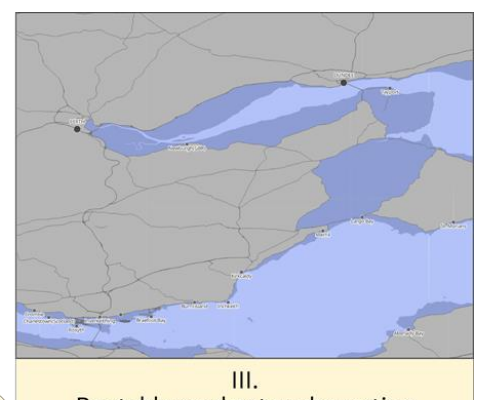

Routable road network creation (source, target, cost)

Figure 3: The road network's creation workflow

Source: own elaboration

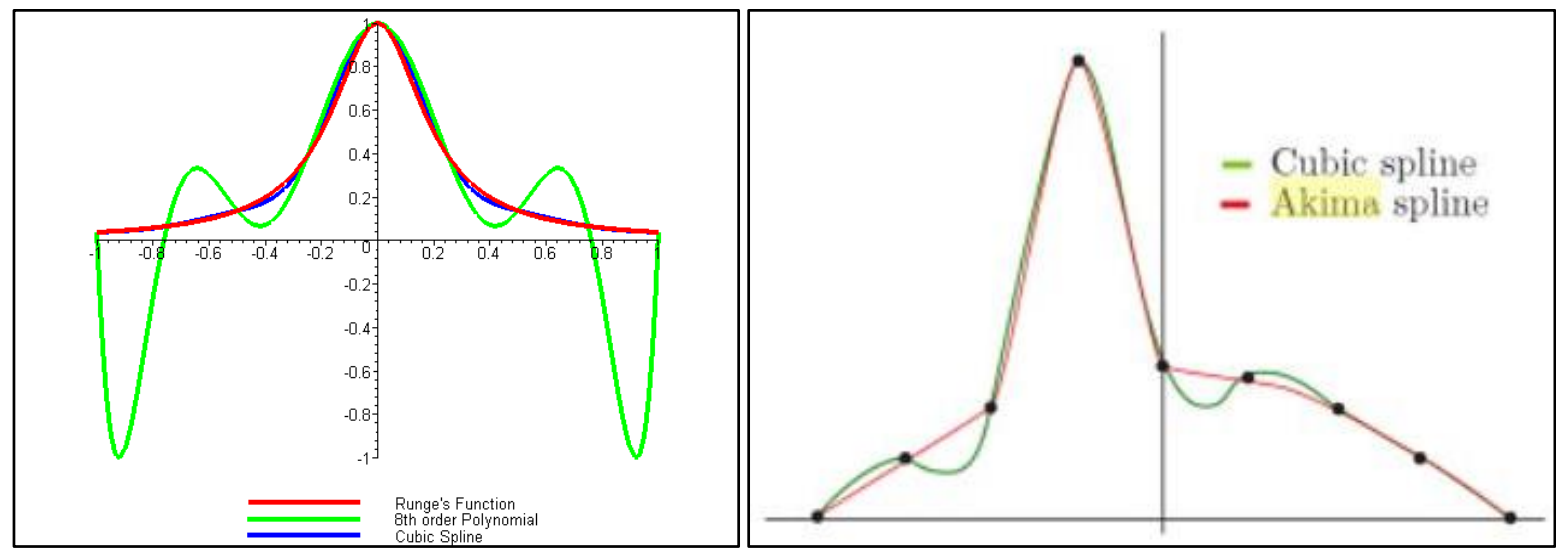

Figure 4: Illustration of interpolation methods

Sources: maplesoft.com (left) and quantmacro.wordpress.com (right) 

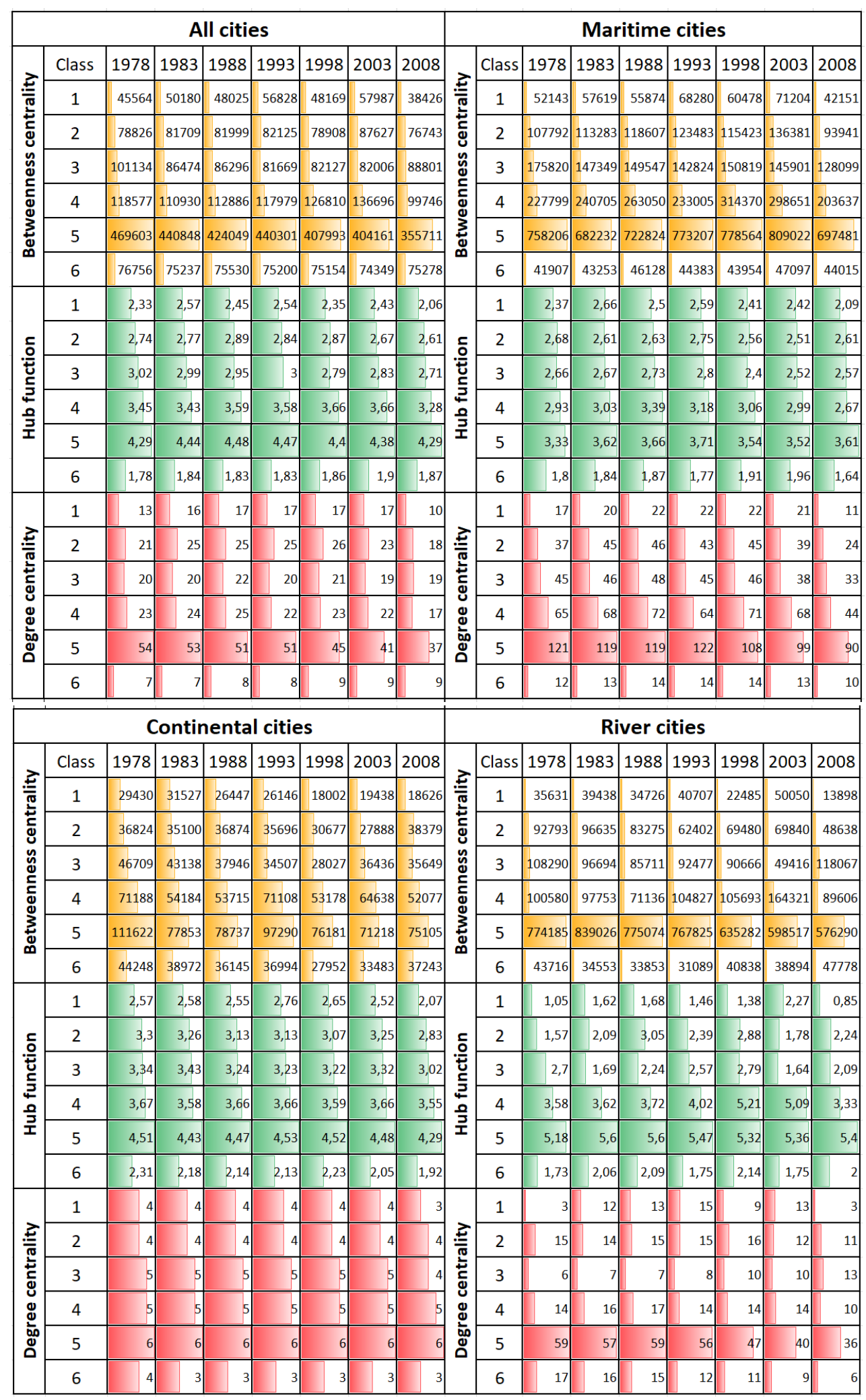

Figure 5: Average centralities per city types and city size classes, 1978-2008

N.B. class 6 corresponds to non-urban ports; classes 1 to 5 are increasingly populated

Source: own elaboration 


\begin{tabular}{|c|c|c|c|c|c|c|c|c|c|}
\hline $\begin{array}{c}\text { Base } \\
\text { indicator }\end{array}$ & $\begin{array}{l}\text { Sea-land } \\
\text { centrality }\end{array}$ & City type & 1978 & 1983 & 1988 & 1993 & 1998 & 2003 & 2008 \\
\hline \multirow{16}{*}{ 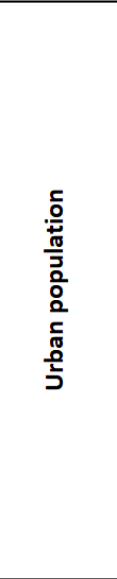 } & \multirow{4}{*}{$\begin{array}{c}\text { Betweenness } \\
\text { centrality }\end{array}$} & Continental & 0,189 & 0,167 & 0,164 & 0,15 & 0,145 & 0,129 & 0,123 \\
\hline & & River & 0,202 & 0,178 & 0,146 & 0,199 & 0,234 & 0,246 & 0,172 \\
\hline & & Maritime & 0,296 & 0,304 & 0,302 & 0,205 & 0,326 & 0,251 & 0,292 \\
\hline & & All & 0,233 & 0,214 & 0,191 & 0,198 & 0,266 & 0,236 & 0,218 \\
\hline & \multirow{4}{*}{$\begin{array}{c}\text { Clustering } \\
\text { coefficient } \\
\text { (inverse) }\end{array}$} & Continental & 0,167 & 0,158 & 0,179 & 0,159 & 0,174 & 0,157 & 0,165 \\
\hline & & River & 0,217 & 0,249 & 0,218 & 0,257 & 0,162 & 0,169 & 0,171 \\
\hline & & Maritime & 0,077 & 0,06 & 0,073 & 0,049 & 0,059 & 0,066 & 0,067 \\
\hline & & All & 0,152 & 0,153 & 0,156 & 0,148 & 0,132 & 0,126 & 0,134 \\
\hline & \multirow{4}{*}{$\begin{array}{l}\text { Degree } \\
\text { centrality }\end{array}$} & Continental & 0,19 & 0,194 & 0,2 & 0,201 & 0,201 & 0,206 & 0,218 \\
\hline & & River & 0,271 & 0,225 & 0,218 & 0,268 & 0,294 & 0,235 & 0,2 \\
\hline & & Maritime & 0,332 & 0,277 & 0,267 & 0,243 & 0,229 & 0,212 & 0,222 \\
\hline & & All & 0,243 & 0,203 & 0,196 & 0,205 & 0,197 & 0,17 & 0,16 \\
\hline & \multirow{4}{*}{$\begin{array}{l}\text { Total traffic } \\
\text { (DWTs) }\end{array}$} & Continental & - & - & - & - & - & - & - \\
\hline & & River & 0,263 & 0,274 & 0,279 & 0,336 & 0,342 & 0,348 & 0,35 \\
\hline & & Maritime & 0,318 & 0,349 & 0,342 & 0,36 & 0,397 & 0,411 & 0,395 \\
\hline & & All & 0,298 & 0,308 & 0,305 & 0,345 & 0,364 & 0,375 & 0,373 \\
\hline \multirow{12}{*}{ 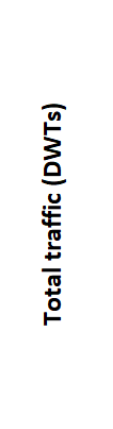 } & \multirow{4}{*}{$\begin{array}{c}\text { Betweenness } \\
\text { centrality }\end{array}$} & Continental & - & - & - & - & - & - & - \\
\hline & & River & 0,987 & 0,989 & 0,989 & 0,988 & 0,974 & 0,945 & 0,953 \\
\hline & & Maritime & 0,744 & 0,754 & 0,751 & 0,74 & 0,655 & 0,679 & 0,665 \\
\hline & & All & 0,9 & 0,908 & 0,899 & 0,889 & 0,813 & 0,794 & 0,812 \\
\hline & \multirow{4}{*}{$\begin{array}{c}\text { Clustering } \\
\text { coefficient } \\
\text { (inverse) }\end{array}$} & Continental & - & - & - & - & - & - & - \\
\hline & & River & 0,271 & 0,323 & 0,315 & 0,33 & 0,159 & 0,223 & 0,176 \\
\hline & & Maritime & 0,187 & 0,171 & 0,203 & 0,244 & 0,184 & 0,202 & 0,225 \\
\hline & & All & 0,225 & 0,218 & 0,24 & 0,271 & 0,173 & 0,207 & 0,203 \\
\hline & \multirow{4}{*}{$\begin{array}{l}\text { Degree } \\
\text { centrality }\end{array}$} & Continental & - & - & - & - & - & - & - \\
\hline & & River & 0,791 & 0,817 & 0,812 & 0,827 & 0,814 & 0,797 & 0,834 \\
\hline & & Maritime & 0,71 & 0,731 & 0,728 & 0,739 & 0,679 & 0,694 & 0,734 \\
\hline & & All & 0,706 & 0,73 & 0,732 & 0,733 & 0,699 & 0,683 & 0,728 \\
\hline
\end{tabular}

Figure 6: Linear correlation (Pearson) evolution between urban population, traffic volume, and types of centralities in the land-sea network by city type, 1978-2008

Source: own elaboration 


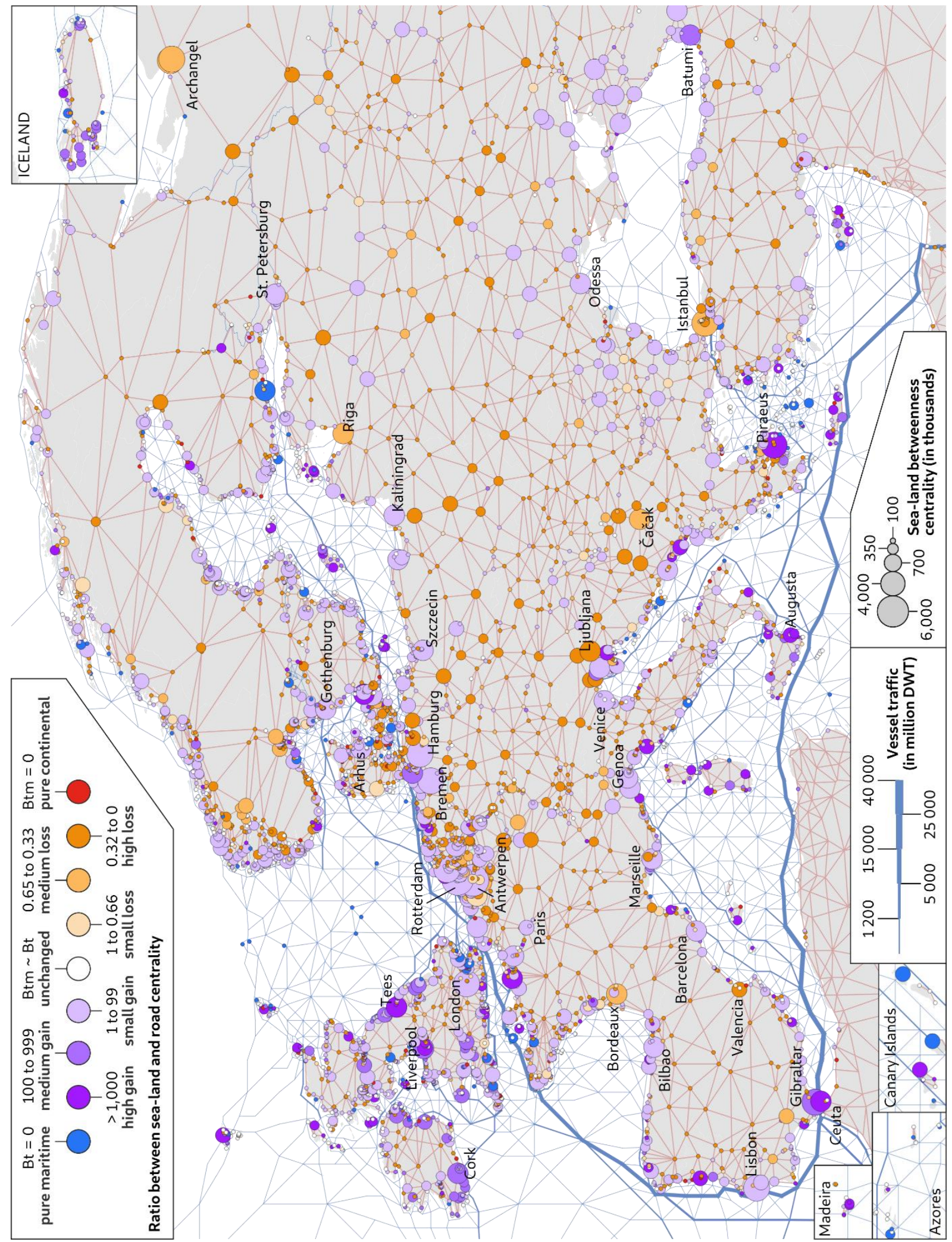

Figure 7: Sea-land centrality and specialization of European ports and cities, 1978

Source: own elaboration 


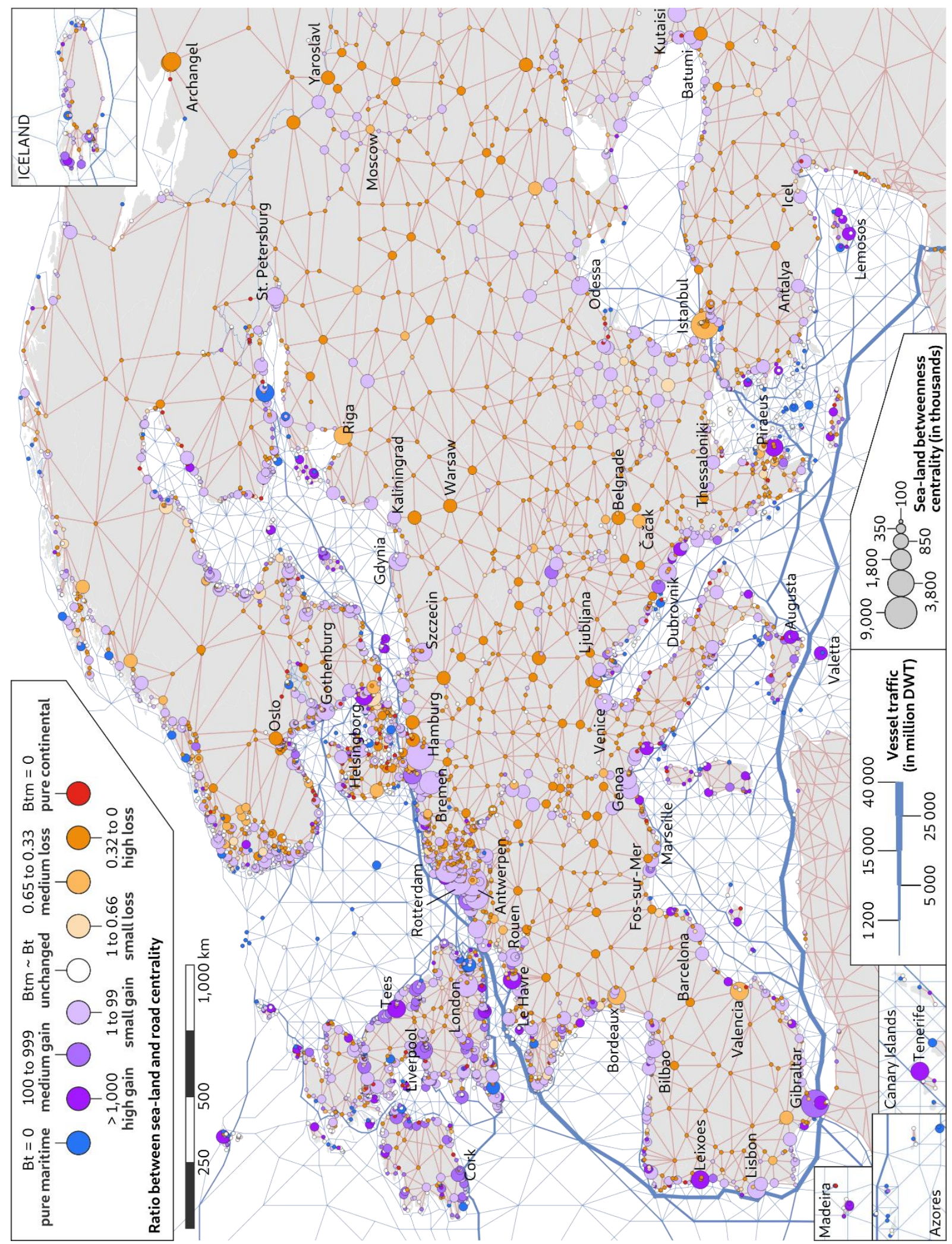

Figure 8: Sea-land centrality and specialization of European ports and cities, 1988

Source: own elaboration 


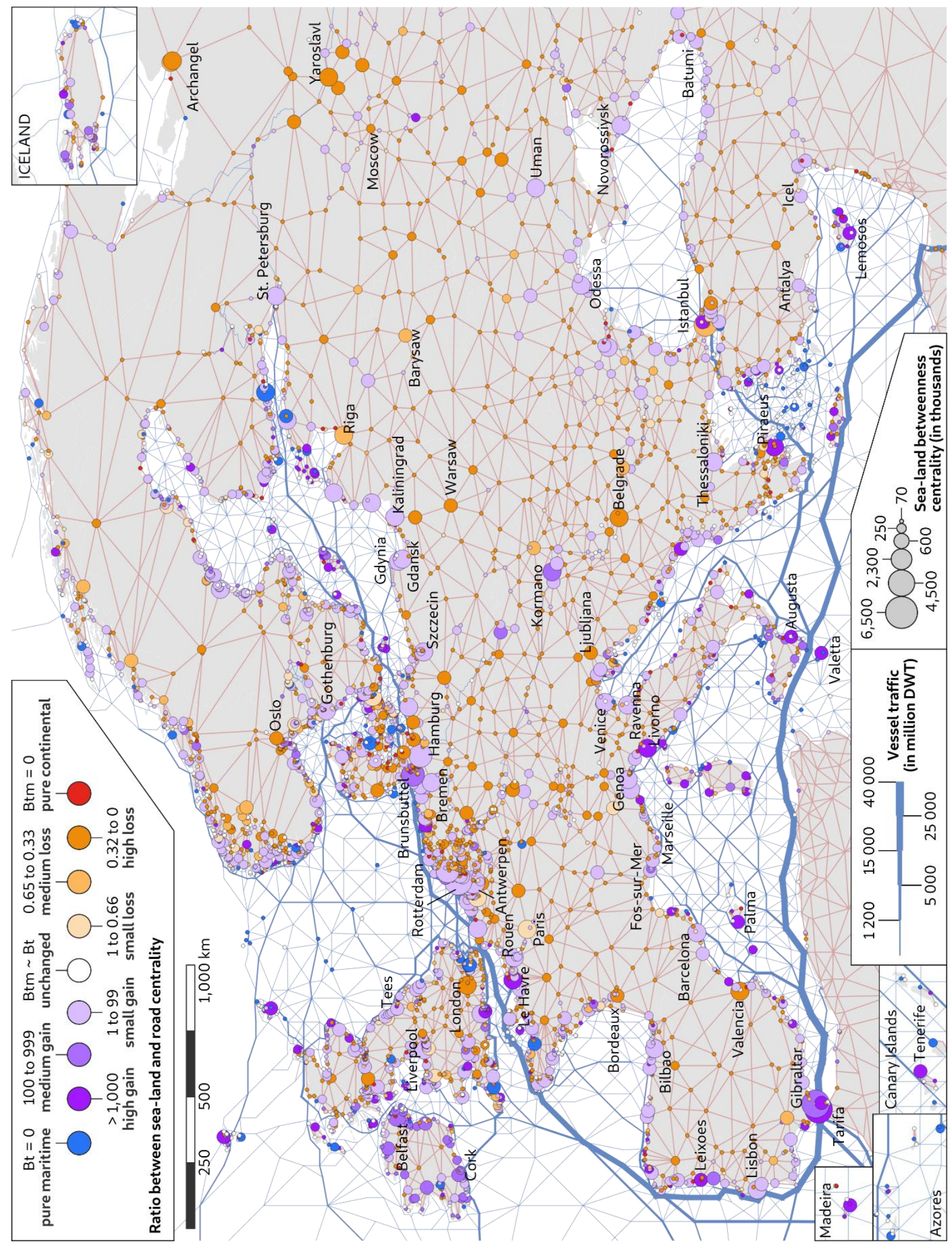

Figure 9: Sea-land centrality and specialization of European ports and cities, 1998

Source: own elaboration 


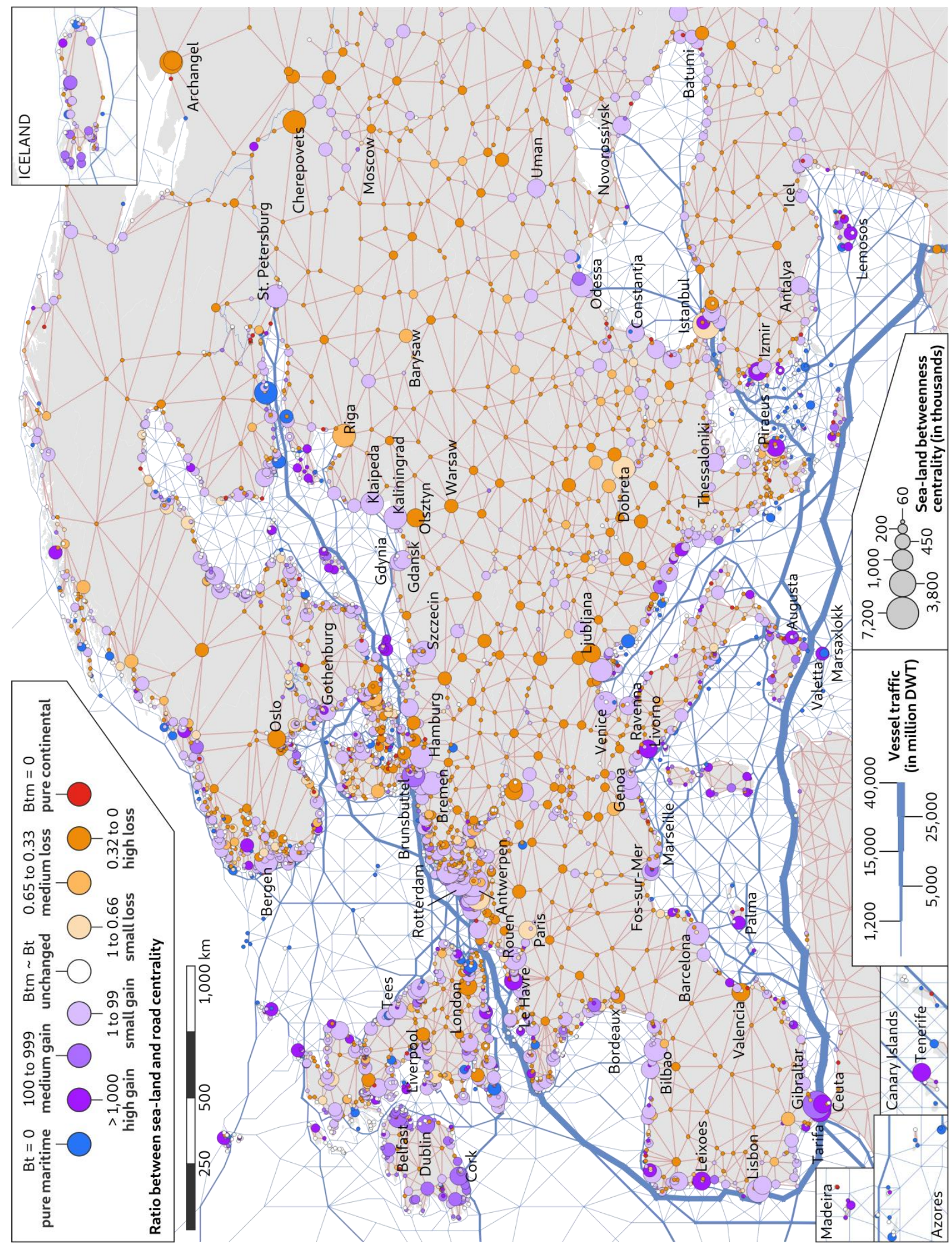

Figure 10: Sea-land centrality and specialization of European ports and cities, 2008

Source: own elaboration 